\title{
Is International Education possible with a Postmodern Approach?
}

\author{
Sirous Tabrizi \\ University of Windsor, Canada
}

\begin{abstract}
Currently, postmodernist thought is common and dominant within education. However, it has been argued that postmodernist thought is incompatible with standardized international education. This incompatibility comes from the argument that postmodernism is relativist in terms of people's opinions, values, and knowledge and that a standardized international education cannot work with such relativism. This paper will argue that the relativistic aspects of postmodernism do not necessarily mean they cannot be used with international education. Thus, this paper will examine postmodernism in education, compare it to modernism in education, and evaluate the two in light of the International Baccalaureate program (as an example of standardized international education). This will show how international education can be conducted within a postmodern society and that many postmodern features are actually more conducive to international education than such features of modernism.
\end{abstract}

\section{Introduction}

Traditionally, major philosophical viewpoints have been grouped into several categories. The most recent categorization is postmodernism, replacing the previous categories of modernism and pre-modernism. Most educational institutions and researchers now find themselves within the postmodern category, regardless of whether they agree with postmodern philosophy. However, those interested in standardized international education may face problems since postmodernism is seen as incompatible given its emphasis on relativism. To better understand whether this is problematic for international education, it is first necessary to see what postmodernism is and how it differs from previous philosophical viewpoints. Thus, this paper will examine postmodernism in more detail and compare it with some fundamental features of international education.

\section{Postmodernism}

One way to describe the differences between modernism and postmodernism is in more behavioral terms. Modernisation refers to economic development that creates social structures through "industrialisation, the growth of science and technology, the modern state, the capitalist world market, urbanisation and other infrastructural elements" [7]. In contrast, post-modernisation refers to 'postindustrial' social and economic structures: secularisation, emphasis on the self and personal growth, and the replacement of production with consumption. The two can also be compared in terms of the metaphysical forms we accept, the organization of knowledge, and the way in which we legitimize beliefs [21; see Table 1 below].

Table 1. Basic differences between Pre-Modern, Modern, and Post-Modernism [13]

\begin{tabular}{|c|c|c|c|}
\hline Topics & Pre-modern & Modern & Postmodern \\
\hline Metaphysic & Super-natural & Naturalism & $\begin{array}{l}\text { Anti-realism, Anti- } \\
\text { idealist, Anti-realist }\end{array}$ \\
\hline Epistemology & $\begin{array}{l}\text { Mysticism, } \\
\text { Faith }\end{array}$ & Reason senses & $\begin{array}{l}\text { Skepticism, } \\
\text { Narratives, Neo- } \\
\text { pragmatist }\end{array}$ \\
\hline Human Nature & $\begin{array}{l}\text { He was born } \\
\text { with sin }\end{array}$ & $\begin{array}{l}\text { Tabularasa } \\
\text { independent }\end{array}$ & $\begin{array}{l}\text { Group-determinism, } \\
\text { Neo-behaviorisms }\end{array}$ \\
\hline Ethics & $\begin{array}{l}\text { Duty, } \\
\text { Sacrifice }\end{array}$ & $\begin{array}{l}\text { Pursuit of } \\
\text { happiness }\end{array}$ & $\begin{array}{l}\text { Conflict, Neo- } \\
\text { existentialism, } \\
\text { Compassion }\end{array}$ \\
\hline Politics & $\begin{array}{l}\text { Hierarchic } \\
\text { authority }\end{array}$ & $\begin{array}{l}\text { Liberty, } \\
\text { Equality }\end{array}$ & $\begin{array}{l}\text { Egalitarianism, } \\
\text { Neo-socialism, } \\
\text { Marxism }\end{array}$ \\
\hline Time Period & $400 s-1400 s$ & $\begin{array}{l}1500 s-1900 s \\
\text { (Renaissance) }\end{array}$ & $1900+$ \\
\hline
\end{tabular}

\subsection{Postmodernism and education}

The theory and practice of education is traditionally founded on modernism, in terms of the assumptions and ideals of that category of thought. For instance, education as a means for transmitting the ideals of critical reason, individual freedom, and progress are all part of modernism [3]. Similarly, the concept of a student as a selfmotivated, self-directed, rational individual is likewise a modernist perspective. However, many of these factors are being challenged by the postmodernist perspective. Postmodernism emphasizes the construction of an individual by external factors (language, contexts), distinct sources of truth, and the role of unconscious desires [9]. In addition, postmodernism directly challenges 
the existing concepts, approaches, processes, structures, and hierarchies of knowledge. Thus, education is not only being challenged by postmodernism but also changing in response to it.

\subsection{Postmodernism and the educator}

From a modernist perspective, the role of education is to help students realize their potential as self-directing and self-motivated agents, so as to become fully autonomous and capable individuals exercising their agency [3]. This involves shaping the subjective perspective of students, or of shaping individuals into particular subjects. From a postmodernist perspective, this role of education is problematic. Postmodernism has a more fluid conception of subjectivity, as there is far greater tolerance and even promotion of diversity and plurality of beliefs [23]. Similarly, the notion that one is socially constructed through external systems implies that the educational system itself is artificial and not a natural or absolute measure for the form a subject should take. As an example of this, [10] has argued that the modernist form of education has attempted to create a certain kind of rational, autonomous individual in a way that institutionalizes "the socialising processes and legitimating codes by which the grand narratives of progress and human development can be passed onto future generations" (pg. 65) [10].

Education itself is changing in its methods, content, and purpose. While not directly related to postmodern thought, these changes are a reflection of the uncertainties associated with postmodernism [3]. As a result, postmodernism influences the discussions and decisions regarding curriculum, pedagogy, structural organization, and role of the educator but does so in a way that these influences are often unseen or subtle. Hence, postmodernist ideas become incorporated into the debates in education, and even changes within the modern practice of education, without actually discussing the real issues associated with postmodernism itself. This could be due to the argument that postmodernism is too critical of a perspective: "the most frequent critique of postmodern thought is [that it is] a rampant relativism, leading to nihilism and social anomie" (pg. 8) [21]. This critique, according to [1], is motivated by the thought that only the two extremes of certainty or chaos are thought to be possible. Hence, postmodernism is rejected without examination because it is assumed that any of the ideas within it are completely incompatible with actual practice. It is not possible for educators to extract themselves from any of these ideas, whether it is of an individualistic (modernist) or critical (postmodernist) kind. Commonly used terms (e.g., progress, empowerment, enlightenment, agency, and development) are all embedded with particular implications and assumptions, and despite the willingness of many researchers and practitioners to question the meanings of these terms they remain part of the discourse of education.

\subsection{Criticism of postmodernism}

An early critique of modernism and postmodernism was that offered by [11], in which he asked, in light of the failures of the twentieth century, whether we "should try to hold on to the intentions of the Enlightenment, feeble as they may be, or should we declare the entire project of modernity a lost cause?" [11] The main criticisms of postmodernism in this work include: (1) postmodernists are equivocal about whether they are producing serious theory or literature; (2) postmodernists are animated by normative sentiments but the nature of those sentiments remains concealed from the reader; and (3) the postmodernist perspective fails "to differentiate phenomena and practices that occur within modern society" [26], and thus ignores everyday life and its practices.

Another significant source of criticism comes from Marxism. This is due to the adoption of postmodernism by radical Anglo-American intellectuals as a coherent critique of modern society in the 1970's [18]. For instance, [4] argues that postmodernists focus so heavily on individual differences that the authority of a liberal state is necessary. This is based on the notion that individual difference cannot be overcome, and hence it is necessary for the state to exist so as to represent and negotiate these differences. However, the Marxist conception of political order and ethics is opposed to this postmodern position: the denial of the working class (or any other subordinate group) as having interests derived from their socioeconomic conditions means any political preference is a moral option, and thus merely a variation of liberalism [4]. The Marxist position tends to use a cognitive and linguistic developmental perspective when addressing psychological issues (e.g., development, affect, neurosis, personality, etc.). Similarly, social theory is a major part of Marxist psychology and education theory as there is no distinction in Marxist thought between social and individual development. In terms of educational theory, Marxist thought is broadly constructivist and emphasizes activity, collaboration, and criticism instead of absorption of knowledge and conformism to specific norms [14]. Thus, the approach to education is student-centered instead of teacher-centered, while still acknowledging the inability of education to overcome the problems, limitations, and potential of its surrounding society. 
A third area of comparison is between postmodernism and constructivism, which is a more subtle comparison that just a Marxist critique of postmodernism. Constructivism is a theory of knowledge that says we build knowledge and meaning from our experiences and ideas [8]. In the early days of constructivist thought, the main exploration was between human experience and behavior (the schemata of Piaget), which led to the constructivism educational theory of Papert and other learning and teaching theories. In education, constructivist learning can be described as students "constructing" their own knowledge by testing ideas from previous experiences and integrating this new knowledge with whatever existed before [8]. Although constructivists have claimed support from researchers such as Dewey, Piaget, Bruner, and Vygotsky there has been mixed and contradictory empirical support. Some have argued that postmodernism is now cemented into educational theory such that other larger theories (e.g., Marxism, liberalism, feminism, etc.) are under threat [14]. A postmodernist approach to knowledge, where struggles are local and particularistic in nature and larger narratives of history are irrelevant, necessarily contradicts other approaches. For instance, [14] argue from a Marxist and constructivist perspective that postmodernism is embedded in educational theory, policy, and practice and that it provides neither a foundation for educational policies nor sufficiently radical educational practice as to challenge capitalist exploitation of people.

\section{International education}

International education is often differentiated from national education by its global focus: a curriculum based on skills and knowledge that are necessary for operating within an increasingly globalized and interconnected world. As an example of international education, this paper will look at the International Baccalaureate (IB) program. IB is a non-profit educational foundation that is recently growing in global popularity [16]. Over the past decade there has been a $10 \%$ annual increase in student enrolment in IB programs, with more than 750,000 students currently enrolled in IB programs in at least 130 countries worldwide [28].

The IB aims to: "develop inquiring, knowledgeable and caring young people who help to create a better and more peaceful world through intercultural understanding and respect. To this end the organization works with schools, governments and international organizations to develop challenging programmes of international education and rigorous assessment. These programmes encourage students across the world to become active, compassionate and lifelong learners who understand that other people, with their differences, can also be right" [15]. The IB's vision is to: "provide a long-term vision of education. It is a set of ideals that can inspire, motivate, and focus the work of school and teachers, unity in a common purpose" [16]. This vision is then translated into learning outcomes, which become part of the Learner Profile (IBLP). The IBLP is a tool for providing a shared vision of dialogue and collaboration among stakeholders (teachers, leaders, students, and the school community) and how to create a superior learning environment [12]. It provides a common language for teachers and administrators to discuss different issues (e.g., student progress, curriculum). In addition, the IBLP provides a means for measuring the realization of the IB program's vision.

The IBLP includes ten attributes (see Table 2) to assist its implementation. These attributes represent the characteristics that should be fostered and developed in all members of the school community (students, teachers, community leaders, etc.).

Table 2. Attributes of the IBLP [12].

\begin{tabular}{|c|c|}
\hline Inquirers & $\begin{array}{l}\text { They develop their natural curiosity. They acquire } \\
\text { the skills necessary to conduct inquiry and } \\
\text { research and show independence in learning. } \\
\text { They actively enjoy learning and this of love of } \\
\text { learning will be sustained through their lives. }\end{array}$ \\
\hline Knowledgeable & $\begin{array}{l}\text { They explore concepts, ideas and issues that have } \\
\text { local and global significance. In so doing, they } \\
\text { acquire in-depth knowledge and develop } \\
\text { understanding across a broad and balanced range } \\
\text { of disciplines. }\end{array}$ \\
\hline Thinkers & $\begin{array}{l}\text { They exercise initiative in applying thinking skills } \\
\text { critically and creatively to recognize and } \\
\text { approach complex problems, and make reasoned, } \\
\text { ethical decisions. }\end{array}$ \\
\hline Communicators & $\begin{array}{l}\text { They understand and express ideas and } \\
\text { information confidently and creatively in more } \\
\text { than one language and in a variety of modes of } \\
\text { communication. They work effectively and } \\
\text { willingly in collaboration with others. }\end{array}$ \\
\hline Principled & $\begin{array}{l}\text { They act with integrity and honesty, with a strong } \\
\text { sense of fairness, justice and respect for the } \\
\text { dignity of the individual, groups and } \\
\text { communities. They take responsibility for their } \\
\text { own actions and the consequences that } \\
\text { accompany them. }\end{array}$ \\
\hline Open-minded & $\begin{array}{l}\text { They understand and appreciate their own } \\
\text { cultures and personal histories, and are open to } \\
\text { the perspectives values and traditions of other } \\
\text { individuals and communities. They are } \\
\text { accustomed to seeking and evaluating a range of } \\
\text { points of view, and are willing to grow from the } \\
\text { experience. }\end{array}$ \\
\hline Caring & $\begin{array}{l}\text { They show empathy, compassion and respect } \\
\text { towards the needs and feelings of others. They } \\
\text { have a personal commitment to service, and act to } \\
\text { make a positive difference to the lives of others } \\
\text { and to the environment. }\end{array}$ \\
\hline Risk-takers & $\begin{array}{l}\text { They approach unfamiliar situations and } \\
\text { uncertainty with courage and forethought, and } \\
\text { have the independence of spirit to explore new } \\
\text { roles, ideas and strategies. They are brave and } \\
\text { articulate in defending their beliefs. }\end{array}$ \\
\hline
\end{tabular}




\begin{tabular}{|l|l|}
\hline Balanced & $\begin{array}{l}\text { They understand the importance of intellectual, } \\
\text { physical, and emotional balance to achieve } \\
\text { personal well-being for themselves and others. }\end{array}$ \\
\hline Reflective & $\begin{array}{l}\text { They give thoughtful consideration to their own } \\
\text { learning and experience. They are able to assess } \\
\text { and understand their strengths and limitations in } \\
\text { order to support their learning and personal } \\
\text { development. }\end{array}$ \\
\hline
\end{tabular}

By practicing to incorporate these attributes into the daily life of the school community, students can become more empowered to pursue a passion for learning, lead lives of integrity, and create more socially responsible solutions to their community's problems [5]. These attributes can also be seen as values. By "value" is often meant "a desirable end state which an individual may consider preferable to others, or a source of inspiration to work towards achieving a goal" [19]. In the context of education, values "help individuals identify, and adopt, personal and social values that they can call on to guide the decisions they make, their relationships, their work and life as a whole" [2]. In examining the values accepted by many cultures across the world, [27] suggests that there are ten motivationally distinct ones: benevolence, selfdirection, universalism, achievement, security, conformity, hedonism, stimulation, tradition, and power (see Table 3). Any alignment between these values and the attributes of the IBLP could potentially increase the effectiveness of implementing the IB program.

Table 3. Values of the IBLP (derived from [27]).

\begin{tabular}{|l|l|}
\hline Benevolence & $\begin{array}{l}\text { Helpful, honest, forgiving, loyal responsible, true } \\
\text { friendship, a spiritual life, mature love }\end{array}$ \\
\hline Self-direction & $\begin{array}{l}\text { Creativity, curiosity, freedom, choosing own } \\
\text { goals, independence }\end{array}$ \\
\hline Universalism & $\begin{array}{l}\text { Protecting the environment, a world of beauty, } \\
\text { unity with nature, broadmindedness, social justice, } \\
\text { wisdom, equality, a world at peace }\end{array}$ \\
\hline Achievement & $\begin{array}{l}\text { Successful, capable, ambitious, influential, } \\
\text { intelligent }\end{array}$ \\
\hline Security & $\begin{array}{l}\text { Clean, national security, social order, family } \\
\text { security, reciprocation of favors, health, sense of } \\
\text { belonging }\end{array}$ \\
\hline Conformity & $\begin{array}{l}\text { Politeness, honoring parents and elders obedience, } \\
\text { self-discipline }\end{array}$ \\
\hline Hedonism & Pleasure, enjoying life \\
\hline Stimulation & A varied life, daring, an exciting life \\
\hline Tradition & $\begin{array}{l}\text { Devoutness, accepting one's portion in life, } \\
\text { humbleness, moderation, respect for tradition }\end{array}$ \\
\hline Power & Preserving one's public image, social recognition \\
\hline
\end{tabular}

\section{Analysis of IB in a postmodern context}

To determine what constitutes a quality curriculum, some set of criteria is necessary. [29] provides a model consisting of four Rs - richness, recursion, relations, and rigor-that can be used as a set of criteria for analysis in a postmodern context. Hence, this model will be used to analyze the IBLP.

\subsection{Richness}

The first $\mathrm{R}$ is richness, which can come from the surrounding culture and its values. One of the most important features of a postmodern curriculum is its openness: the ability to generate multiple understandings, having multiple layers of interpretation, and presenting different realms of meaning [22]. Openness creates not only an exciting curriculum but also one that is more similar to the current view of the world. Richness is necessary to create openness. By having a curriculum that is rich, there is ambiguity, challenge, and encouragement for debating the meaning of the content. Since meaning-making occurs through dialogue and interaction, there needs to be sufficient depth and breadth (richness) in the curriculum.

In the IB education system, richness can be seen in the skills that students develop at the primary level (i.e., the Primary Year Program). First, students are encouraged to be inquirers. The curriculum emphasizes developing the natural curiosity of students, such that they acquire the skills necessary to conduct inquiry and research and to show independence in learning. This also helps to develop a love of learning. Second, students are encouraged to be thinkers. They are given support to critically and creatively apply thinking skills to recognize and approach complex problems. In addition, they are encouraged to make reasoned and ethical decisions. Third, students are encouraged to be principled. They act with integrity and honesty, and with a strong sense of fairness, justice, and respect for the dignity of individuals, groups, and communities. They take responsibility for their own actions and the consequences that accompany them. Finally, students are encouraged to be open-minded. They are taught to understand and appreciate their own cultures and personal histories, while still being open to the values and traditions of other individuals and communities. Throughout the curriculum, they are accustomed to seeking and evaluating a range of points of view, and are willing to grow from the experience. These four skills help to create the openness that [22] argues is necessary for richness.

\subsection{Recursion}

The second $\mathrm{R}$ is recursion, which can come from understanding oneself and others. Although recursion means "to return," in the humanities it has the broader meaning of turning around and reflecting on oneself [22]. In the context of 
education then, recursion means discussing one's own thoughts to others and then turning around and reconsidering these thoughts. A recursive curriculum allows students to loop back to previous ideas, revisit what has previously happened or been taught, and creates a non-linear sequence; rather than a definite linear sequence of plans and material, a non-linear sequence is open and allows stronger dialogue between students, teachers, the material, and the wider society.

In the IB education system, students are encouraged to not only understand but also express ideas and information with each other. This expression should be a display of confidence and creativity, and mediated through multiple means of communication and languages. Students willingly work in collaboration with others, and are encouraged to show empathy, compassion, and respect towards the needs and feelings of others. This is connected to a personal commitment to service, so that students act to make a positive difference in the lives of others and the wider environment. Such a system encourages dialogue between students, leading to increased opportunities for reflection.

\subsection{Relation}

The third $\mathrm{R}$ is relation, which emerges from the intercultural values that are part of an internationalized education. A linear curriculum is structured such that it has a defined beginning, middle, and end. However, the structure of a nonlinear curriculum has no defined beginning or end; it simply has a middle that is filled with many interconnected points. As the number of possible connections between points increases, either explicitly through the curriculum or from the active questioning by students, the complexity and richness of the curriculum also increases [22]. This reinforces and augments the previous two Rs: the degree of relations in the curriculum increases the quality of both richness and recursion.

In the IB education system, having a high degree of interconnectedness can be seen from its aims. Since the IB organization works with multiple schools, governments, and international organizations the resulting programs are necessarily complex. Similarly, students are engaged in both studies and practical work within their communities. This gives them opportunities for interaction within a larger and more complex system than the typical simplified classroom.

\subsection{Rigor}

The fourth and possibly most important $\mathrm{R}$ is rigor, which arises from a demanding curriculum. Rigor provides the structure and order necessary to create a coherent and dynamic unity among the interconnected material and processes of a rich and recursive curriculum [22]. Rigor is also the struggle in which students engage to work through any presented problems and achieve a sense of coherence and integration. It is only from rigor that coherence and order is able to emerge from the otherwise chaotic and confusing complexity of the curriculum.

For the IB education system, rigor can be seen in a few places. First, it is seen in the degree to which the IBLP is methodologically rigorous. Second, it is seen in the career-related program (CP), in which interested students can pursue a career-related education in the final two years of secondary school [17]. Thus, students can continue the regular IB education while participating in studies related to a particular career. The $\mathrm{CP}$ is adapted to meet the needs, backgrounds, and contexts of students, while also incorporating the rigor of IB Diploma Program courses, the components of the $\mathrm{CP}$ core, and individual careerrelated studies.

\section{Implementation of IB in a postmodern society}

The societal conditions that affect the implementation of an international education program can be briefly analyzed in terms of four concepts: knowledge, culture, value, and human nature. The view that a society has on these four concepts influences the kind of education that can be implemented, since community members will either reinforce the curriculum or implicitly encourage students to fight against it.

\subsection{Knowledge}

[25] Has suggested that a common focus for schools is standardized testing. The problem with such testing is that it creates rigid boundaries between subject areas and imposes knowledge on students, in the sense of seeing whether students have reached the same conclusion as the test creator. In contrast, a more postmodern approach to knowledge would be to assess the knowledge constructed by students. The thinking that is often needed within a postmodern system is systems thinking, where systems thinking can be considered as embracing the whole since the whole is often more than the sum of its parts [6]. Postmodernity and systems thinking share several characteristics, including connectedness, integration, and openness. Just as systems thinking examines objects as a whole of interconnected parts, postmodernity views the world as a system of interconnected parts. In an educational context then, postmodern educators 
should be facilitators and co-constructors of knowledge. In the IB program, students are asked to reflect on the nature of knowledge, and how we know what we claim to know. Doing so is much easier in a society in which educators believe they are facilitators rather than transferring information that will later be tested for accuracy.

\subsection{Culture}

It can be argued that the modernist method of unifying society results in domination and exploitation, due to the emphasis on the dominant culture. In a postmodern sense, cultures are not only of equal value but also equally important realities. Thus, part of a postmodernist approach to education is the empowerment of students from a non-dominant culture to fight against the dominant one (typically European or Western) [7]. One of the goals of international education, such as the IB program, is to prepare students for an increasingly multicultural and globalised world. This requires not only acceptance of other cultures but also the realization that the dominant culture is not necessarily the best or better one. Hence, a postmodern society is better able to engender the kind of culture which an international education needs.

\subsection{Value}

In a postmodern education system, students should be encouraged to construct diverse and personally useful values in the context of their own culture. In doing so, the values are those considered useful and not necessarily true or right in any universal sense. Teachers are allowed to openly promote their values and social agendas in the classroom, as it is impossible for them to avoid teaching their own values. In order to create an education system matching postmodern goals, it is important that students are at least exposed to the values of diversity, tolerance, freedom, creativity, emotion and intuition. This is consistent with the approach taken by the IB program towards values, which are meant to help individuals "identify, and adopt, personal and social values that they can call on to guide the decisions they make, their relationships, their work and life as a whole" [2].

\subsection{Human nature}

A postmodern education is seen as one where students are able to construct their own identity. This is in contrast with the idea that through exposure to topics and others students will "discover" their identity. The progress of individuals and society as a whole occurs when people are empowered to attain their chosen goals.
It is this view of human nature that is part of a postmodern education, and this view is needed for a postmodern education to occur. In the IB program, such a view of human nature is seen in the IBLP. Rather than evaluating the progress of students based on a program-wide goal, the IBLP evaluates students based on how well they have achieved goals specific to them [20]. Furthermore, the IBLP can provide school-wide reflection and analysis. For instance, teachers and administrators could ask: 'To what extent do our philosophy, school structures, curriculum, and units of work enable students, and the adults who implement the programs, to develop into the learner described in the profile?' It is important to note that the profile does not provide answers to these questions; instead, it provides a structure in which these questions can be asked and answers explored [20].

\section{Conclusion}

When we look at the world from a postmodern perspective, we see that previous views are no longer applicable; it is insufficient to view things from the perspective of an overarching monoculture or in terms of dominant patriarchal discourses (e.g., white and Eurocentric) with 'outsider' marginalized subcultures and groups existing on the fringes. The promotion and the inclusion of these previously marginalized voices into regular discourse are necessary for the continued functioning of society.

The successful implementation of the IBLP depends on the culture and the ethos of the school. In a school that has a commitment to the values inherent in the IBLP, these values will be readily apparent in all aspects of the school. The shared vision and common language provided by the IBLP encourages collaboration and dialogue about how to create the best environment for learning. Since the IBLP is flexible, innovative and creative, teachers from many different cultures can play a very significant role in the development of each program. Such a role is pivotal in the IB's model for the development and implementation of each program, and it will be the same for the successful introduction of this key cross-program component. Successful implementation of the IBLP in a school will result in a learning environment in which the aims and values of the IB programs are strongly evident and embraced by all members of the community. This is the real challenge for the IBLP, but it is more readily achievable in a postmodern context. 


\section{References}

[1] Bernstein, R.J., Beyond objectivism and relativism: Science, hermeneutics, and praxis, Blackwell Publishers, 1983.

[2] C. Drake, Values education and life-wide learning, 1999, ttp://www.livingvalues.net/reference/learning.html.

[3] Cobley, E., Modernism and the culture of efficiency: Ideology and fiction, University of Toronto Press, Toronto, 2009.

[4] Eagleton, T., Ideology: An Introduction (Vol. 9), Verso, London, 1991.

[5] Ellwood, C., and M. Davis, International Mindedness: A professional development handbook for international schools, Optimus Education eBooks, 2009.

[6] F. Betts, "How systems thinking applies to education," Educational Leadership, vol. 50, no. 3, 1992, pp. 38-41.

[7] Featherstone, M., Consumer culture and postmodernism (2nd ed.), Sage Publications, California, 2007.

[8] Fosnot, C. T., Constructivism: Theory, perspectives, and practice, Teachers College Press, 2013.

[9] Foucault, M., The Archaeology of Knowledge [Translated from the French by AM Sheridan Smith], Pantheon Books, 1972.

[10] Giroux, H., Teachers as Intellectuals: Towards a Critical Pedagogy of Learning, Bergin and Garvey, South Hadley MA, 1988.

[11] Habermas, J., The inclusion of the other: Studies in political theory, MIT Press, Cambridge MA, 2000.

[12] Hayden, M.C., and J.J. Thompson, International Schools and International Education: Improving Teaching, Management, and Quality, Kogan Page, London, 2000.

[13] Hicks, S. R., Explaining postmodernism: Skepticism and socialism from Rousseau to Foucault, Scholargy Publishing, Inc, 2004.

[14] Hill, D., P. McLaren, M. Cole, \& G. Rikowski, G. (Eds.), Marxism against postmodernism in educational theory, Lexington Books, 2002.

[15] International Baccalaureate Organization (IBO), Towards a Continuum of International Education, Cardiff, 2008.

[16] International Baccalaureate Organization (IBO), "International Baccalaureate Program", 2011, http://www.ibo.org/programmes/profile/.
[17] International Baccalaureate Organization (IBO), "Career-related Programme: The Core," 2014, http://www.ibo.org/globalassets/digital-tookit/flyers-andartworks/cp-core-en.pdf.

[18] J. Beinin, "Marxism and Postmodernism," MER 187 - Humanitarian intervention and North-South Politics in the 1990's, vol. 24, 1994.

[19] J. Wells, "International education, values and attitudes: A critical analysis of the International Baccalaureate (IB) Learner profile", Journal of Research in International Education, vol. 10, no. 2, 2011, pp. 174188.

[20] K. Bullock, "International Baccalaureate learner profile: Literature review," International Baccalaureate, 2011 ,

http://www.ibo.org/contentassets/2470e1b3d2dc4b82 81649bc45b52a00f/iblearnerprofileeng.pdf.

[21] Kvale, S. (Ed.), Psychology and postmodernism (Vol. 9), Sage Publications, California, 1992.

[22] L.J. Starr, "A critique of the international baccalaureate learner profile as a curricular document: context, hegemony, hermeneutics, and the four Rs", Yonsei Journal of International Studies, 2009, pp. 115124.

[23] Lash, S., Sociology of postmodernism, Routledge, United Kingdom, 1990.

[24] Lyotard, J.F., The postmodern condition: A report on knowledge (Vol. 10), University of Minnesota Press, 1984.

[25] N.S. Lewis, "The intersection of post-modernity and classroom practice," Teacher Education Quarterly, 2004, 119-134.

[26] Ritzer, G., and J. Stepnisky, Sociological Theory (9th ed.), McGraw-Hill Higher Education, New York NY, 2013.

[27] S.H. Schwartz, G. Melech, A. Lehmann, S. Burgess, M. Harris, and V. Owens, "Extending the cross-cultural validity of the theory of basic human values with a different method of measurement", Journal of CrossCultural Psychology, vol. 32, no. 5, 2001, pp. 519-542.

[28] Tarc, P., Global dreams, enduring tensions: International Baccalaureate in a changing world, Peter Lang, 2009.

[29] W.E. Doll, Jr, "Curriculum Possibilities in a "Post"Future," Journal of Curriculum and Supervision, vol. 8, no. 4, 1993, pp. 277-292. 